\title{
Fraude en interne controle
}

\section{Voorkomen is beter dan genezen}

Oscar van

Leeuwen

\section{Imtech}

Afgelopen najaar doken in de kranten voor het eerst berichten op dat het met de cijfers van het snel groeiende bedrijf Imtech niet helemaal goed zou zitten. Imtech is een Europese technische dienstverlener op het gebied van elektrotechniek, ICT en werktuigbouw. Met circa 30.000 medewerkers realiseert Imtech opbrengsten van ruim $€ 5$ miljard op jaarbasis. Een analistenrapport van ABN AMRO gaf ultimo 2012 aan dat Imtech te veel geld nodig heeft voor de financiering van zijn activiteiten. Er werd in dit rapport gewezen naar de Duits-Poolse activiteiten. Imtech reageerde buitengewoon fel en kritisch op dit rapport.

In december 2012 kwam tevens naar voren dat de gedeponeerde jaarrekeningen van Ventilex, een dochter van Imtech, volgens Hof Leeuwarden valsheid in geschrifte zou bevatten. Dit werd overigens tegengesproken door Imtech.

Op 2 februari 2013 werd naar aanleiding van de accountantscontrole echter duidelijk dat er bij een pretpark in Polen in de buurt van Warschau grote tekorten bleken te bestaan die in eerste instantie werden geschat op $€ 100$ miljoen. Tevens gaf de accountant aan de jaarstukken niet te kunnen goedkeuren. Op 2 februari halveert de koers van Imtech op de beurs.

In latere uitingen van Imtech lopen de geschatte tekorten op tot $€ 370$ miljoen. In juli 2012 was de opdracht voor het Poolse Pretpark nog door Imtech aangekondigd als de grootste opdracht van Imtech ooit.

Het management in Polen wordt op 4 februari ontslagen en er wordt een forensisch onderzoek opgestart. Op 5 februari worden twee van de vier Duitse bestuurders van Imtech ontslagen in verband met hun betrokkenheid bij de Poolse activiteiten.

De VEB vraagt Imtech op 5 februari 2013 om opheldering over het systeem van interne controle. Imtech beantwoordt deze brief op 4 maart waarbij met name verwezen wordt naar lopende onderzoeken en er geen geruststelling kan worden gegeven dat de situatie in Polen het enige probleem is. Wel wordt aangegeven dat de langetermijndoelstellingen worden losgelaten en de focus in 2013 komt te liggen op het aanscherpen van de operationele uitvoering van de bedrijfsprocessen.
Uiteindelijk besluit Imtech tot een claimemisse om circa $€ 500$ miljoen op te halen.

Op 3 april krijgt Imtech een nieuwe CEO Gerard van de Aast. In een interview op Business News-radio op 21 mei 2013 geeft hij aan dat de oorzaken van de problematiek zaten in onvoldoende business controls en fraude door het management. Tevens geeft hij aan na te willen gaan of het mogelijk is de in eerdere jaren aan het management kennelijk onterecht betaalde bonussen terug te vorderen. In een report to shareholders van Imtech van 18 juni 2013 worden de volgende fraudes genoemd: "inflated financial information, start van het project in Polen zonder financiering, transacties met de X-group van circa Eur 30 miljoen een frauduleuze derde partij zonder duidelijke reden.”

\section{Is Imtech de uitzondering op de regel?}

De vraag komt bij het lezen hiervan op of de situatie rondom Imtech nu een uitzondering op de regel of het topje van de ijsberg is. Er zou betoogd kunnen worden dat de combinatie van een snelle groei met een decentrale wijze van aansturing een organisatie als Imtech gevoelig maakt voor dit soort problemen. Anderzijds is het helder dat Imtech niet het enige bedrijf is waar iets mis is gegaan. $\mathrm{Na}$ de deconfitures van Enron en Worldcom en in het verlengde daarvan de teloorgang van Arthur Anderson hield het maar niet op. Bij Parmalat bleken bankrekeningen voor in totaal $€ 6$ miljard niet te bestaan. Ook het Indische IT bedrijf Satyam hield het niet droog. Bij de Franse Bank Société Générale bleek een 32-jarige beurshandelaar (Jerôme Kerviel) in zijn eentje in staat allerhande transacties te sluiten die hij nooit alleen ${ }^{1}$ had mogen sluiten, leidend tot een verlies van $€ 4,9$ miljard. De resulterende koersval van de aandelen schokte het vertrouwen in de financiële sector leidend tot het faillissement van enkele banken.

In Nederland kenden wij onder meer de Peper-affaire en de bouwfraude. Daarnaast miste bij Ahold nogal wat omzet en ook de oliereserves van Shell bleken niet bewezen te zijn terwijl het concern jarenlang gedacht had dat ze wel bewezen waren, enzovoorts.

\section{Is regelgeving het antwoord?}

Om dit soort situaties een halt toe te roepen besefte men 
in Amerika in de zomer van 2002 dat spoed geboden was. Daarom werd in acht weken tijd door de Senatoren Sarbanes en Oxley een wet ontworpen om het vertrouwen in de kapitaalmarkten te herstellen. Deze wet werd op 31 juli 2002 door president Bush getekend. Het Nederlandse antwoord hierop van de Commissie-Tabaksblat is ultimo 2003 gelanceerd. Doel hiervan is een goed systeem van corporate governance bij de Nederlandse organisaties te bewerkstelligen. Want 'een goed systeem van corporate governance draagt bij aan een goed functionerende economie' (Commissie Corporate Governance, 2003, p. 66). In de Sarbanes Oxley Act staat met name adequate financiële verslaglegging centraal. Bij de Nederlandse corporate governance code wordt zowel een verantwoordelijkheid bij het bestuur gelegd (namelijk de verantwoordelijkheid voor de kwaliteit en de volledigheid van de openbaar gemaakte financiële berichten) als bij de raad van commissarissen die erop toe moet zien dat 'het bestuur deze verantwoordelijkheid vervult'. Ook in andere landen zijn vergelijkbare codes en wetten verschenen. Dat lijkt dus wel goed te zitten, maar kennelijk is het hebben van strengere regels alleen niet voldoende om te voorkomen dat het misgaat...

\section{Hoe kun je als bestuurder en commissaris invulling geven aan deze verantwoordelijkheid?}

Inherent aan de rol van het management is het beinvloeden van het gedrag van de werknemers om de organisatiedoelstellingen te bereiken. Daarnaast maakt het management zelf echter ook onderdeel uit van de interne beheersingsomgeving. Bij Imtech en de andere al genoemde financiële schandalen speelde het management zelf een belangrijke rol die uiteindelijk leidde tot onjuiste informatieverstrekking aan de voornaamste stakeholders van de organisatie. Het management is immers zelf in staat het stelsel van interne beheersing te doorbreken. Denk hierbij aan het doorbreken van de door het management zelf aangebrachte controletechnische functiescheidingen (tegengestelde belangen), en het negeren van de voor het management uitgevoerde verbands- en detailcontroles en cijferbeoordelingen. Dit gevaar wordt wel aangeduid met de term management override. De positie die het management in de organisatie inneemt, zorgt er qualitate qua voor dat dit risico altijd aanwezig is. Zie ook Van Leeuwen en Wallage (2010, 2011). Daarom is er bij het voorkómen van dit soort problemen een belangrijke rol weggelegd voor het management en de toezichthouders $(\mathrm{RvC})$ van een organisatie. Imtech spreekt zelf van het scheppen van een "open en sceptical corporate culture.”

Het management van een organisatie kan zelf bij het beoordelen van de werking van de interne beheersingsomgeving onder meer gebruikmaken van de volgende instrumenten: a. Het ondertekenen van een Letter of Representation (LOR), waarin expliciet de juistheid van de verantwoordingsinformatie in combinatie met de werking van de interne beheersingsomgeving wordt getoetst. Hiermee wordt het probleem van het vaststellen van de goede werking van de interne beheersingsomgeving (deels) gedelegeerd. Het risico van bias door het tekenende (lagere) management is hierbij uiteraard aanwezig, aangezien dit in feite een vorm van zelfcontrole door het (lagere) management betreft. Een ander risico van een dergelijke 'zelfevaluatie' is het risico dat het management niet van alle feiten en gebeurtenissen op de hoogte is. De RvC dient in elk geval kritisch met het hogere management te bespreken in hoeverre de handtekeningen door het lagere management terecht gezet zijn (professioneel kritische houding van de $\mathrm{RvC}$ ). Tevens kan de $\mathrm{RvC}$ zelf enkele gesprekken voeren met het tweedelijnsmanagement aan de hand van de vragenlijsten en de van het management ontvangen rapportages om zo een gevoel te krijgen bij de rol van de directie binnen de interne beheersingsomgeving.

b. Een afzonderlijke functionaris (eventueel een daarin gespecialiseerde eigen medewerker of externe functionaris) de werking van de interne beheersingsomgeving laten toetsen door het kennisnemen van verslagen en conclusies, het houden van interviews en het uitvoeren van enquêtes. Indien deze taak door de interne accountantsdienst (IAD) wordt uitgevoerd moet hierbij uiteraard wel bedacht worden aangezien de IAD als verbijzonderd element van interne controle aan het management van de organisatie rapporteert - dat er een rechtstreekse communicatielijn tussen de IAD en de $\mathrm{RvC}$ is. Uiteraard neemt de $\mathrm{RvC}$ ook kennis van constateringen van externe accountants op het vlak van de werking van de interne beheersingsomgeving zoals deze meestal in de management letter zijn opgenomen.

c. Het stimuleren van een onafhankelijk gepositioneerde rapportagelijn inzake ongewenste afwijkingen die zich binnen de interne beheersingsomgeving voordoen (een zogenoemde klokkenluidersregeling).

De Association of Certified Fraud Examiners (ACFE, 2012) adviseert om in combinatie hiermee medewerkers te trainen in:

a. wat fraude is;

b. hoe fraude iedereen in de organisatie raakt;

c. hoe te rapporteren over zaken die het daglicht mogelijk niet verdragen kunnen.

Het blijkt namelijk dat maar liefst $47 \%$ van alle fraudes ontdekt wordt op basis van tips van eigen medewerkers. Daarmee zijn eigen medewerkers verreweg het meest effectieve instrument om fraude te ontdekken.

Doel van al deze activiteiten is een cultuur te scheppen die fraude voorkomt. Er blijft vervolgens voor de RvC dan 
nog één vraag over. Het management is als eindverantwoordelijke voor de interne beheersingsomgeving in staat om de binnen de organisatie aangebrachte functiescheidingen te doorbreken en de rapportages inzake het functioneren van de interne beheersingsomgeving aan te laten passen. De RvC zal zichzelf de vraag moeten stellen of een dergelijke aanpassing (veelal in combinatie met het manipuleren van de resultaten van de organisatie) door het management wel of niet heeft plaatsgevonden.

Leveren bovengenoemde maatregelen een onbevredigend resultaat op dan rest de $\mathrm{RvC}$ slechts als optie vanuit haar verantwoordelijkheid als toezichthouder in te grijpen.

\section{Hoe krijg je dit voor elkaar?}

Uiteindelijk moeten de aandeelhouders de commissarissen en de bestuurders voldoende scherp zien te krijgen. Kennelijk vervullen bestuurders en commissarissen de hierboven aangegeven werkzaamheden nog lang niet altijd op een voldoende niveau. Kennis van inter- ne controle mag hier niet bij ontbreken. Een goed bestuurder mag immers niet verrast worden. Naar mijn mening moet:

a. een opleiding voor managers en commissarissen interne controle verplicht in hun opleiding opnemen;

b. in elke $\mathrm{RvC}$ een professional op het gebied van internal control zitting hebben;

c. in meer algemene zin een register worden aangelegd van commissarissen die de juiste opleiding doorlopen hebben om de rol van commissaris te kunnen vervullen.

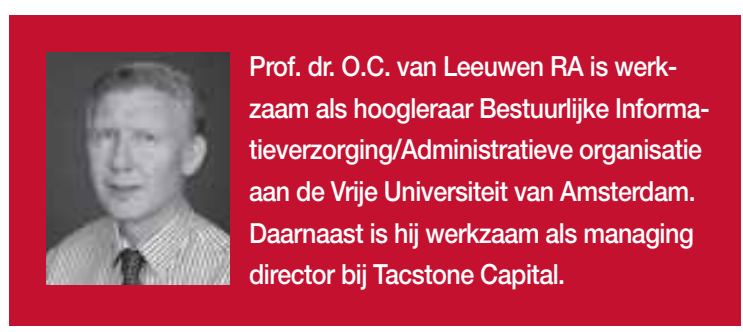

$\underline{\text { Noot }}$

Zie: 'Kerviel handelde als in een computerspel. Realiteit drong nog maar op schaarse momenten door tot megafraudeur SocGen'.

In: Financieel Dagblad 29 januari 2009.

\section{Literatuur}

- Association of Certified Fraud Examiners (ACFE) (2012). Report to the nations on occupational fraud and abuse. 2012 Global fraud study. Geraadpleegd op http://www.acfe.com/ uploadedFiles/ACFE_Website/Content rttn/2012-report-to-nations.pdf.

- Commissie Corporate Governance (Tabaksblat
2003). De Nederlandse Corporate Governance Code: beginselen van goed ondernemingsbestuur en best practice bepalingen, Den Haag: VNO.

- Leeuwen, O.C. van, \& Wallage, P. (2011). Het toetsen van de werking van de interne beheersingsomgeving door de Raad van Com- missarissen. Maandblad voor Accountancy en Bedrijfseconomie, 85(9), 437-444.

- Leeuwen, 0.C. van, \& Wallage, P. (2010). Het evalueren van de interne beheersingsomgeving. Een onderbelicht thema. Maandblad voor Accountancy en Bedriffseconomie, 84(9), 447-457. 